\title{
A Comparative Global Geothermal Development Analysis: Indonesia Investment Perspective
}

\author{
Noeroso L. Wahyudi \\ Fiscal Policy Office, Ministry of Finance, Indonesia \\ nlwahyudi@yahoo.com,nlwahyudi@fiskal.go.id
}

\begin{abstract}
One of the current suggestions on low global oil price is a good momentum to optimize utilization of geothermal resources as renewable energy. Meanwhile, Government and donors countries have partnership experiences to remove some barriers such as legal framework on business process for attracting private sectors to invest on geothermal project financing. An explorative analysis on comparative global geothermal development based on Indonesia investment perspective is methodology of this paper. As a qualitative-descriptive paper, this method focused on literature review to obtain literature or secondary data. The data used are secondary data obtained from various sources, such as, Ministry of Energy and Mineral Resources (MEMR), Ministry of Finance, PT PLN as well as a range of research and other resources accessed through the internet. The goal of these explorations to find some lessons learnt which might be used by the GoI to utilize its largest world potential of geothermal resources more transparent, efficiently, and effectively. Based on global geothermal development current status shows that the role of private companies in Indonesia position is the second ranking on share geothermal utilization. Unfortunately, Indonesia position on share of resource to potential utilization is in the third ranking compare to six leading geothermal countries. This mean that Indonesia has opportunity to scale up its resource potential utilization. Managing this opportunity, the GoI should continue its experience to support and guarantee private companies business process strategically.
\end{abstract}

Keywords: Global Geothermal, Business Strategies, Indonesia Experience

\section{Introduction}

Global geothermal opportunity and barrier: History of the first global Geothermal Generation Status began over 100 years ago and the first large scale generation operated over 50 years ago (Lawless, 2013). Countries along Latin America's Pacific Coast and in the Caribbean have significant geothermal resources. However, these potential resources have been underexploited. It is estimated that only $4-5 \%$ of geothermal energy's potential has been developed in this region (Bruni, 2014).Similarly, total global potential resources utilization is estimated around $10 \%$ (Rahardjo, 2013). In addition, Bruniclaims when the price of global crude oil drops, it is a time to seize the moment of geothermal energy. Meanwhile, in general there are 2 (two) barriers namely uncertain economics and uncertain environment (Rahardjo, 2013). Uncertain economics contains some barrier such as i) High upfront capital requirement and ii) Uncertainty on pricing. Similarly, uncertain environment contains some barrier such as i) Regulatory uncertainty and ii) other risk. In term of financing, construction of a geothermal power plant requires a huge initial cost of the project economics, i.e. upstream side (including exploration), pipeline system and power plant which can be divided into 4 (four)stages namely: i)Preliminary Survey, ii) Exploration, iii) Exploitation, iv) Commercial. To solve these barriers , there are some different government supports to optimize its resource utilization.

Government support experience: The role of government support on business strategy determines the success of global geothermal investment including Indonesia (Campen, 2015). In addition, some studies have been conducting some experts facilitated by multilateral agencies, such as ADB, (Asian Development Bank and WB. (World Bank) One of these studies has been published on, "Unlocking Indonesia's Geothermal Potential". This report provides useful insights to policy makers, investors, geothermal industry practitioners, and all geothermal development stakeholders for global geothermal countries especially Indonesia. Specifically, this report identifies the main issues that are hindering geothermal power development and reviews geothermal related policies and regulations in Indonesia.

Objective of the study: Considering on history, moment on scale up, barrier of geothermal development and the role of government and donor support, there is a need an explorative study on global geothermal development in some leading countries. The goal of this study is to find some lessons on geothermal energy on global and domestic experience and suggest to the GoI formulize more attracting policy on private 
companies to invest in geothermal energy. In general, this paper will present comparative progress and the role of government experience to support for utilizing geothermal as renewable energy globally. Specifically, this paper present Indonesia experience on legal reform to promote private company business process on geothermal project development gradually.

A way forward: The result of an explorative study based on literature review and Indonesia case analysis will be presented on this paper. The result of this study is to suggest the GoI (Government of Indonesia) to continue for implementing strategic policy especially for attracting private companies. This suggestion is very useful to scale up geothermal energy domestically resulted in increasing on share of private companies to global potential on geothermal resource utilization.

The methodology of this paper is an explorative study. Briefly, this explorative study is a combination between literature review and secondary data analysis for finding some lesson learns on appropriate global and domestic experience. These findings are very important for justification to provide better regulation based on private business practices in future. The secondary data obtained from various sources, such as, Ministry of Energy and Mineral Resources (MEMR), Ministry of Finance, PT PLN (State Electricity Company) as well as a range of research and other resources accessed through the internet

As mentioned in introduction, there is a long history in global geothermal development. This imply that there are many experience can be explore especially on government regulation and donor support to improve private companies to invest on geothermal energy. Consequently, there are two session to achieve the goal of this study namely, i) Literature review, and ii) Analysis. In the literature review, this paper presents an explorative reference related to: i) progress of global geothermal development, i) the role of government and donors in, iii) Global status Indonesia in geothermal development, iv) Comparative investment policy. In analysis session, this paper discusses how to attract private companies through legal reform and harmonize major stakeholders on geothermal development.

Based on global exploration, analysis session present domestic experience focus on two issues on legal framework stage namely: i) Periodically stages on geothermal business process, ii) The main government stakeholders on geothermal investment. The first issue discuss on stage of legal related to business process and industrial performance. The second issue discuss on the main government stakeholders on issuing regulation based on existing regulations to remove the barriers of geothermal development in Indonesia.

\section{Literature Review}

Progress Global Geothermal Development. At present, installed geothermal power generation capacity worldwide is around $12.6 \mathrm{GWe}$ in 2015. This amount is spread into 9 (nine) leading countries such as i) USA, ii) Philippines, iii) Indonesia, iv)Mexico, v)New Zealand, vi)Iceland, vii) Kenya, viii) Japan, and ix) Turkey . The first leading country is USA which has installed geothermal capacity around 3,450 MW. The second leading country is the Philippines with 1,850 MW, and the third country is Indonesia with 1,340 MW. The following geothermal power producers countries are Mexico, New Zealand, Kenya, Japan and Turkey. These counties develop each installed capacity are 1,058 MW, 1,005 MW, 665 MW, 636 MW, 519 MW and 407 MW (Bertani, 2016). In the future Indonesia has opportunity to be as a super power in geothermal utilization (Al Gore, 2011). To response this opportunity, some studies have been conducted to scale up the prospect of geothermal development for the future (Ardyansah, 2013, Jacques, 2014, and ADB and WB, 2015). One of the barriers to realize this opportunity is how to mitigate risk of global power development including in the early phases before test drilling for estimate the size and nature of the underlying resource (Vernier \& Jaudin, 2013). Specially. Indonesia and the Philippines face other for geothermal development risk such as : a) High upfront cost of investment and resultant cost of electricity production; b) Extensive initial geotechnical work required; c) High complexity of planning needed for variable timelines and costs (depending on outcomes of drilling and exploration); d) Long lead times; e) Regulatory risk and bureaucracy (weak policy coordination between the central and regional governments); f) Legal certainty (paras 19, ADB CTF Private Sector Geothermal Program: Indonesia and Philippines,2016). 
The Role of Government Support: The characteristic of geothermal business is promising on to realize energy security based on sustainable energy. On the other hand, there are many barriers on stages development namely: i) pre exploration, iii) exploration, and iii) exploitation or commercial of this energy. Based on these stages, there is necessary to make summary on the role of government to promote geothermal development among leading countries. The government support on pre exploration is government funded on research. This support is very important to estimate the proven of geothermal can produce energy for electricity. The other important support is government funded on drilling, incentive price on renewable energy, generators. Completive price on electricity market is also very important government role. Last but not least central government is very important to role to coordinate with local government. A comparative on the role of government on among 6 (six) leading geothermal countries can be seen table 1 bellow.

Table 1: A comparative on the role of government among 6 (six)) Leading Geothermal Countries

\begin{tabular}{|c|c|c|c|c|c|c|c|}
\hline No. & Country & $\begin{array}{l}\text { Government } \\
\text { funded } \\
\text { research? }\end{array}$ & $\begin{array}{l}\text { Govt. } \\
\text { funded } \\
\text { drilling? }\end{array}$ & Generators & $\begin{array}{l}\text { Price } \\
\text { incentives } \\
\text { For } \\
\text { renewables? }\end{array}$ & $\begin{array}{l}\text { Vertically } \\
\text { Integrated? }\end{array}$ & $\begin{array}{l}\text { Electricity } \\
\text { market }\end{array}$ \\
\hline 1. & USA & Yes & No & $\begin{array}{l}\text { IPPs and } \\
\text { utilities }\end{array}$ & Yes & Mostly & Open \\
\hline 2. & Philippines & Minor & $\begin{array}{l}\text { Yes in } \\
\text { past }\end{array}$ & $\begin{array}{l}\text { IPPs and } \\
\text { SOEs }\end{array}$ & No & Some & Open \\
\hline 3. & Indonesia & Minor & Minor & $\begin{array}{l}\text { in past IPPs } \\
\text { and SOEs }\end{array}$ & No & Mostly & $\begin{array}{l}\text { State } \\
\text { monopoly }\end{array}$ \\
\hline 4. & Mexico & Minor & $\begin{array}{l}\text { Yes by } \\
\text { SOE }\end{array}$ & SOE & No & Yes & $\begin{array}{l}\text { State } \\
\text { monopoly }\end{array}$ \\
\hline 5. & $\begin{array}{l}\text { New } \\
\text { Zealand }\end{array}$ & Yes & Yes & $\begin{array}{l}\text { in past } \\
\text { Mostly IPPs }\end{array}$ & No & Yes & Open \\
\hline 6. & Iceland & Yes & Yes & $\begin{array}{l}\text { in past IPPs } \\
\text { and utilities }\end{array}$ & No & Yes & Open \\
\hline
\end{tabular}

Source : Lawless, 2013

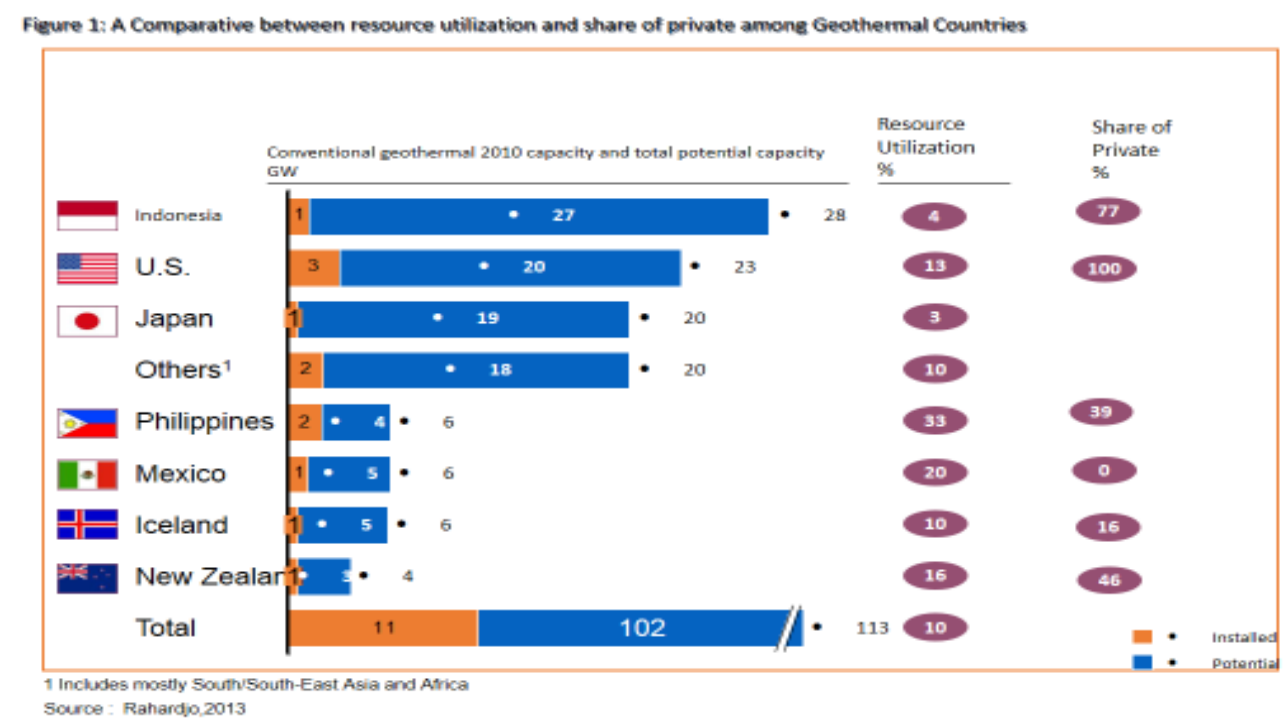

Table 1 shows that the role of government USA give the most comprehensive support among the six leading geothermal development with give government funded research and price incentive for renewable energy. While government of Philippine opens its electricity market, Indonesia government set state monopoly on its electricity market 
Global Status Indonesia on Geothermal Development: As mentioned above, Al Gore describes that Indonesia could become a super power country in electricity production from geothermal energy in the future. This description is justified that Indonesia has highest potential capacity as shown figure 1 above. Figure 1 describe that Philippine is the first position on resource utilization with $33 \%$ and Mexico is the second position on resource utilization with $20 \%$. While, USA is the third position with $14 \%$ and Indonesia is the seventh with $4 \%$ above Japan position is the eight with $3 \%$. In the future, Indonesia could become a super power country in electricity production from geothermal energy and this would benefit its economy (Al Gore, The Climate Project Asia Pacific Summit, 2011). This description suggest that the GoI (Government of Indonesia) should explore best practices on global geothermal governance to reform country strategy geothermal development especially in promoting private climate investment efficiently and effectively. As a result, best practices experience in global and domestic on private business process based on existing legal should be used as reference to scale up geothermal project development.

Comparative Investment Policies. History on comparative analysis on investment policies in developing countries give a lesson how to identify the role of stakeholder to scale up geothermal utilization. The exploration the role of stakeholders to promote investment policies can be seen on table 2 below.

Table 2: Comparative Investment Policies on Developing Countries

\begin{tabular}{|c|c|c|c|}
\hline No. & Countries & History & Present \\
\hline 1. & Philippines & $\begin{array}{l}\text { had } 2 \text { large waves of geothermal development } \\
\text { under government and donor-lead }\end{array}$ & $\begin{array}{l}\text { more private sector but with } \\
\text { significant support policies }\end{array}$ \\
\hline 2. & New Zealand & Major state support from 1950s-1980s & virtually no state support \\
\hline 3. & Kenya & $\begin{array}{l}\text { significant donor and state support, including } \\
\text { state-company exploration }\end{array}$ & \\
\hline 4. & Chile & $\begin{array}{l}\text { liberal electricity market framework with } \\
\text { limited geothermal support }\end{array}$ & $\begin{array}{l}\text { (but new government is designing } \\
\text { policies with multilateral } \\
\text { organizations) }\end{array}$ \\
\hline 5. & Indonesia & $\begin{array}{l}\text { Assignment of geothermal concession to SoE } \\
\text { Development Rights Granted under } \\
\text { Presidential Decree } 45 / 1991\end{array}$ & $\begin{array}{l}\text { More transparent for Private } \\
\text { Involvement Geothermal Law } \\
27 / 2003 \text { amended no } 21 / 2014\end{array}$ \\
\hline
\end{tabular}

Source: Campen, 2015 and Ibrahim, 2015

Table 2showsthat Indonesia more aggressive on relaxing legal barrier to scale up geothermal development. The new regulation states that geothermal is not the mining activity because geothermal areas are mostly in the protected forest area that does not allow for mining activities. Furthermore, private entities can compete with State owned enterprises and possible to be a government partner through Public Partnership (PPP) scheme..Since commercial stage is indication of the success on geothermal development, some countries issue FIT ( feed in tariff) to attract private investment. WB and ADB explore feed in tariff in some countries that can be seen on table 4 .

Table3: Global Comparative on Feed in Tariffs

\begin{tabular}{llll}
\hline Countries & Size & Currency/kWh & $\mathbf{U S} \mathbb{\mathbf { k }} \mathbf{k W h}$ \\
\hline Indonesia & & & $7-18.5$ \\
Philippines & & & 0.0 \\
Germany & & $0.25 €$ & 33.7 \\
Japan & $<15 \mathrm{MW}$ & $27,3 \mathrm{Y}$ & 26,6 \\
& $>15 \mathrm{MW}$ & $42.0 \mathrm{Y}$ & 40.9 \\
Italy & $<1 \mathrm{MW}$ & $0,20 \mathrm{E}$ & 27,0 \\
Taipei, China & & W,80 NTS & 17,0 \\
\hline
\end{tabular}

Note: In Indonesia and the Philippines, geothermal resources are found at depths of up to 2-3km underground. Source: WB and ADB 2015

Table 3indicates the different of rate FIT is meaningful between developing countries such as Indonesia, and Taipei, China, and developed countries such as Japan, and European centuries. This means that "affordable 
price " is one of the factors a key success on FIT or Public Private Partnership scheme on a renewed wave of infrastructure finance (Nishizawa, 2016).

Critical on Government Support: As mentioned above exploration stage is critical point which need government support. The table 4 below describe summary on best practices scheme on geothermal exploration.

Table4: Summary of Geothermal Exploration Support Schemes on some countries

\begin{tabular}{|c|c|c|c|c|c|c|c|}
\hline No & Country/Scheme & Nature & $\begin{array}{l}\text { Premium } \\
\text { Required }\end{array}$ & Scope & $\begin{array}{l}\text { Cap/ } \\
\text { project } \\
\$ \text { million }\end{array}$ & \% Cover & $\begin{array}{l}\text { Criteria } \\
\text { for } \\
\text { Payment }\end{array}$ \\
\hline 1. & Germany & & & & & & \\
\hline 1.a.i & Federal & Loan & No & $\begin{array}{l}\text { Drilling and } \\
\text { heat plant }\end{array}$ & $\begin{array}{l}3.5 \text { per } \\
\text { well } \\
\text { and } 2.8 \\
\text { for } \\
\text { the heat } \\
\text { plant }\end{array}$ & 80 & Completion \\
\hline 1.a.ii & & $\begin{array}{l}\text { Drilling } \\
\text { Risk } \\
\text { Cover }\end{array}$ & No & Drilling & 1.8 & $\begin{array}{l}50 \% \text { of } \\
\text { originally } \\
\text { Planned } \\
\text { costs }\end{array}$ & Failure \\
\hline 1.a.iii & & $\begin{array}{l}\text { Exploration } \\
\text { Risk Cover }\end{array}$ & $\begin{array}{l}\text { Higher } \\
\text { interest } \\
\text { rate while } \\
\text { drilling, } \\
10 \%-20 \%\end{array}$ & Drilling & None & $\begin{array}{l}80 \% \text { of } \\
\text { drilling } \\
\text { Costs }\end{array}$ & Failure \\
\hline 1.b.i & State & Loan & No & Drilling & 1.3 & 25 & Failure \\
\hline 1.b.ii & Commercial & Insurance & Yes & Drilling & Partial & & Failure \\
\hline 2. & Switzerland & Risk cover & No & $\begin{array}{l}\text { Drilling and } \\
\text { testing }\end{array}$ & $50-80$ & & Failure \\
\hline 3. & France & Risk cover & Yes & $\begin{array}{l}\text { Whole } \\
\text { project }\end{array}$ & & Up to 90 & Failure \\
\hline $\begin{array}{l}4 . \\
5 .\end{array}$ & $\begin{array}{l}\text { Australia } \\
\text { US }\end{array}$ & Grant & No & Drilling & 4.7 & 50 & Completion \\
\hline i. & UCCDP & Loan & No & Drilling & & $20-90$ & Failure \\
\hline Ii & GRCP & Loan & No & $\begin{array}{l}\text { Drilling and } \\
\text { geosciences }\end{array}$ & 3 & $50-90$ & Failure \\
\hline 6. & Iceland & Loan & No & $\begin{array}{l}\text { Drilling and } \\
\text { geosciences }\end{array}$ & & 60 & Failure \\
\hline 7. & World Bank & & & & & & \\
\hline 7.i. & GeoFund & Risk cover & No & Drilling & & Up to 80 & Failure \\
\hline 7.ii & ARGeo & Risk cover & Yes & Drilling & & Up to 80 & Failure \\
\hline
\end{tabular}

Source: (ADB, World Bank Publication, 2015

Note: $\mathrm{ARGeo}=$ African Rift Geothermal Development Program (World Bank), GeoFund = Geothermal Energy Development Program, GRCP = Geothermal

Reservoir Confirmation Program (US), UCCDP = user-coupled confirmation drilling program, US = United States. Notes: Only the more relevant schemes are included in the table. Drilling usually includes well testing and stimulation (if used).

In the recent articles on Mechanism of Fiscal and Taxation Policies in the Geothermal Industry in China (Yong, 2016), review that Geothermal projects are capital-intensive and high-risk. Fiscal and taxation policies that could support the different phases of geothermal development are important to take into consideration 
(Campen and Petusdottir, 2016).Furthermore, Public mechanisms for supporting investments in geothermal energy exist at many countries. Kaneko argued that implementation of fiscal and taxation assistance such as Feed-in Tariff, tax-reduction, government subsidy for survey and construction cost would bring significant benefits both to the government and to the society. He estimated impact on electricity price if the subsidy had been issued to construction of the geothermal power plant based on Japanese model and he found that when the subsidy is granted $20 \%$ of the construction cost instead of $0 \%$, the selling price could be economized by USD 1.3 cent/kWh less (Kaneko, 2010 and Hayashi, 2015).

\section{Results}

Indonesia investment perspective: In Statistical Highlights, Indonesia is top three of Top five countries for installed capacity in 2015 with 1340 MWe under USA and Philippine with 3450 MWe and 1670 MWe. In addition Indonesia is number five for "Top Five Countries" for absolute value increase with only $12 \%$ since 2010. Surprisingly, Turkey is number one of Top five countries for the absolute increase in $306 \mathrm{MWe}$ MWe since WGC2010 (Bertoni,2015). Even though Indonesia position on resource utilization and share of resource to potential utilization are in the third among the six position compare to some leading geothermal countries, but the role of private company in Indonesia position is the first ranking on share geothermal utilization (see table 2).This current status means that there is opportunity for the GoI to scale up share of resource utilization through adopting the first and second leading counties experience. The first leading contrary experience is to facilitate research especially on provided reliable data potential government and formulize appropriate scheme of government support on exploration. The second leading countries experience is to release the price the market. As a result, the government support and donor participation for increasing coordination among related government institutions and market players towards more competitive Investment climate in Indonesia. On the other word, , if government give more attractive support to new geothermal project, then private companies will be as a major stakeholder to accelerate electrification ratio based on renewable energy.

In future, the increasing of share private companies because business process on geothermal development is more transparent in Indonesia (table 2).The more transparent process indicates that previous business structure model all geothermal working areas (GWA) are exclusive to be managed by National Oil Company (Pertamina) as SOE. Now, GWAs can be managed by private entities through tender process. In other words, the difference between previous and current business structure is tender process to stimulate more transparent on business process. So private companies act as second party not as third party to its steam product to utilities company (PLN). In investment perspective, The geothermal market in Indonesia can be viewed through the interaction of various stakeholders on both the legal and commercial fields or business process (Hermawan, 2015).

Legal framework stage: Periodically, the geothermal business process can be divided in three stages namely i) before year 2003, before year 2014 and after year 2014. These periodically stages can be seen into table 5 bellow. 
Table 5: Periodically stages on Geothermal Business Process in Indonesia

\begin{tabular}{|c|c|c|c|c|}
\hline No. & Periodically Stages & Legal & Business process & Industrial Performance \\
\hline \multirow[t]{2}{*}{1.} & $\begin{array}{l}\text { Before year } 2003 \\
\text { "Mining Activities" }\end{array}$ & $\begin{array}{lr}\text { Precedential } & \text { Decree } \\
\text { (PD) No. } & 22 / 1981, \\
\text { amended } & \text { and } \\
\text { supplemented } & \text { by } \\
45 / 1991 \text { PD } \\
49 / 1991\end{array}$ & $\begin{array}{lr}\text { Assignment } & \text { to } \\
\text { Pertamina } & \text { and } \\
\text { private company } \\
\text { as third party } \\
\text { (investor) } r \text { and } \\
\text { deal with } & \text { PLN } \\
\text { (Public } & \text { Utility } \\
\text { Company) }\end{array}$ & $\begin{array}{l}\text { 11 geothermal power } \\
\text { projects/ energy sales } \\
\text { contracts were concluded for } \\
\text { total capacity } 3,417 \text { MW, } \\
\text { involving approx. USD } \$ 4 \\
\text { Billion investment }\end{array}$ \\
\hline & & $\begin{array}{l}\text { PD } 76 / 2000 \text { was } \\
\text { enacted }\end{array}$ & $\begin{array}{l}\text { the exploratory } \\
\text { risk from } \\
\text { developer to GOI \& } \\
\text { to remove the les } \\
\text { specialist tax } \\
\text { Government }\end{array}$ & $\begin{array}{l}\text { almost no new investment to } \\
\text { explore new work areas since } \\
\text { issuance of PD } 76 / 2000 \text { \& Law } \\
\text { No. } 27 / 2003\end{array}$ \\
\hline 2. & $\begin{array}{l}\text { After year } 2003 \text { to } \\
\text { Before year } 2014 \\
\text { "Mining Activities/ } \\
\text { Law No. } 27 \text { Year } \\
2003 \text { on Geothermal }\end{array}$ & $\begin{array}{l}\text { FIT (Feet in Tariff) has } \\
\text { been launched }\end{array}$ & $\begin{array}{l}\text { Support on } \\
\text { exploration, } \\
\text { construction and } \\
\text { operation. }\end{array}$ & $\begin{array}{l}\text { Indonesia has more than } 285 \\
\text { locations along the country, } \\
\text { yet only less than } 5 \% \text { of total } \\
\text { potential reserves have been } \\
\text { utilized with total installed } \\
\text { capacity of geothermal energy } \\
1,226 \mathrm{MW}\end{array}$ \\
\hline 3. & $\begin{array}{l}\text { After year 2014 : } \\
\text { More "industry- } \\
\text { friendly/Law No. } 21 \\
\text { Year 2014 on } \\
\text { Geothermal }\end{array}$ & $\begin{array}{l}\text { More supportive legal } \\
\text { framework } \\
\text { continued to enhance } \\
\text { and to intensify } \\
\text { cooperation rith } \\
\text { donors countries. }\end{array}$ & $\begin{array}{l}\text { the distinction } \\
\text { between direct } \\
\text { utilization } \\
\text { activities and } \\
\text { indirect utilization } \\
\text { activities and the } \\
\text { centralization of } \\
\text { government for } \\
\text { authority indirect utilization } \\
\text { indivities. }\end{array}$ & \\
\hline
\end{tabular}

Source : Juniarto, 2015,and some various publications,2016

In term of fiscal policy, the GoI experience give support on geothermal business process depend upon Ministry of Finance as Chief of Financial officer and Ministry of Mineral and Energy Resources (MEMR), Ministry of State Owned Enterprises (SOE) and Ministry of Home Affair (MOHA) as Chief of Operational Officers). The role of those ministries can be seen on table 6 below.

Table 6: The Main Government Stakeholders on Geothermal Investment in Indonesia

\begin{tabular}{lll}
\hline $\begin{array}{l}\text { The main government } \\
\text { stakeholders }\end{array}$ & Concerned about & Impact \\
\hline $\begin{array}{l}\text { Ministry of Finance (MoF),/Law } \\
\text { No. 17 Year 2000 on Public }\end{array}$ & $\begin{array}{l}\text { Government support to scale up } \\
\text { geormal development conducted }\end{array}$ & $\begin{array}{l}\text { To enhance public funding } \\
\text { instrument and aware on Risk } \\
\text { Finance, Law no, 1 year 2004 } \\
\text { on Treasury. }\end{array}$ \\
$\begin{array}{l}\text { by State Owned Enterprise and } \\
\text { pritigation. A series regulations } \\
\text { credible fiscal policy. }\end{array}$ & $\begin{array}{l}\text { on government support have } \\
\text { been issued (Dina Irvina,2014) }\end{array}$ \\
$\begin{array}{l}\text { Resources (MEMR)/Law No. 30 } \\
\text { Year 2009 on Electricity }\end{array}$ & $\begin{array}{l}\text { resulted from Renewable energy } \\
\text { especially from geothermal. setting } \\
\text { the satisfactory commercial }\end{array}$ & $\begin{array}{l}\text { Law to promote energy security } \\
\text { and formulize Feed In Tariff. } \\
\text { (Halstead, M., et.al, 2015) }\end{array}$ \\
The Ministry of State Owned & To assign SOE as Agent of & Pertamina reluctant to allocate \\
\hline
\end{tabular}




\begin{tabular}{llll}
\hline $\begin{array}{l}\text { Enterprises (SOE) /Lawno 19 } 19 \\
\text { year2003 on SOE }\end{array}$ & $\begin{array}{l}\text { Development especially } \\
\text { geothermal utilization based } \\
\text { business conduct. }\end{array}$ & $\begin{array}{l}\text { on } \\
\text { on }\end{array}$ & $\begin{array}{l}\text { equity capital to PGE when } \\
\text { compared to the much higher } \\
\text { returns available in Pertamina's } \\
\text { oil and gas plays } \\
\text { Pet benefit for local people. }\end{array}$ \\
$\begin{array}{l}\text { Local Government/ } \\
\text { Lawno. 33 year 2004 on Fiscal } \\
\text { Balance. }\end{array}$ & &
\end{tabular}

Source: Various Publications 2016

In general, table 6 above describe existing role of government to promote climate investment which generate more transparent business process towards sustainable energy resulted from scale up geothermal utilization. Unfortunately, The GoI still face some policy issues to remove barrier in private companies to invest in geothermal project. One of policy issues that still under discussion is government guarantee on a range of unspecific risks including technical (geological) risks, regulatory risks stemming from uncertain government policy, and financial risks arising from the pricing policies determined by the Indonesian Government. The other challenge is structural issues. The structural issue in the Indonesian geothermal sector is the conflicting objectives of the main government stakeholders to attract private intend to invest on geothermal project in feasible rate of return To manage this challenge, the strategic policy is to reform fiscal policy especially to enhance government support and government guarantee. At present, fiscal reform has been launched is to increase fiscal by reducing energy subsidy and miss targeting electricity subsidy beneficiaries. In the sense of MoF as fiscal authority should provide the necessary subsidy especially energy subsidy. On table 6describe the role of MoF should cover the cost production of geothermal based on ensure economic efficiency. Meanwhile MEMR as a sectors supervision must ensure the project will operate effectively. So strategically communication in term of fiscal efficiency and fiscal risk should be conducted based on benefit among stakeholders consistently.

\section{Conclusion and Recommendations}

Exploration on Global comparative geothermal development indicates some interesting findings such as: i)Total global resources utilizations is only $10 \%(11 \mathrm{GW})$ compare to its potential capacity (113 GW) , ii)there are 3 (three) global leading countries namely, USA, Philippine and Indonesia. iii) Indonesia private sector share more than State owned Enterprises and its ranking position is number two in global geothermal development by operator type (figure 1), iv) government and donor support play a key role on geothermal development. In analysis on Indonesia investment perspective, government have attracted private companies since 1991 gradually. Specifically, government have released some legal barriers on business process, harmonized among existing legal frameworks, and supported and guaranteed through fiscal policy included FIT on geothermal energy. As a strategic policy on pricing geothermal energy, government should reformulate FIT based on legal reference and possibly audited professionally and independently. If this strategic policy can be implemented in the future, then the role of private companies will be more important to scale up geothermal energy domestically and globally.

\section{References}

Al Gore, L. (2011)> The Climate Project Asia Pacific Summit, http://indonesia.gr/indonesia-can-be-superpower-on-geothermal-energy-al-gore/downloaded on September 27,2016.

Bertani, R. (2016). Geothermal power generation in the world 2010-2014 update report. Geothermic, 60, 3143. Cited on ADB CTF Private Sector Geothermal Program: Indonesia , Philippines.

Bruni, S. (2014). Geothermal Energy: a Sustainable Source of Power, IDB and Energy Innovation Center, 2014.

Campen, B. V. \& Rai, K. (2015). Geothermal Policy and Regulation-Cases from Chile, Kenya, New Zealand and the Philippines; Technical Report; University of Auckland Geothermal Institute; International Renewable Energy Agency (IRENA): Auckland, New Zealand; August 2015.

Campen, V. B. \& Petursdottir, H. (2016). Geothermal sustainability regulation in Iceland and New Zealand. In Proceedings of the European Geothermal Congress 2016, Strasbourg, France, 19-24 September 2016. 
Hayashi, M., Kuge, K., Sato, H. \& Tanaka, H. (2015). Cooperation in geothermal development at Great Rift Valley in Africa. In Proceedings of the World Geothermal Congress 2015, Melbourne, Australia, 19-25 April 2015

Hermawan, J. (2015). Geothermal power projects in Indonesia, March 2015.

Ibrahim, R., Fauzi, A. \& Suryadarma, I. (2005). The progress of geothermal energy resources activities in Indonesia. In Proceedings of the World Geothermal Congress 2005, Antalya, Turkey, 24-29 April 2005.

Jacques, H. (2014). June 30, 2014, Indonesia: The Slow Boil Geothermal Super Power Nikkei, Asian Review.

Kaneko, M., Kaneko, M. M., Akakura, K., Yamamur, S. \& Inoue, Y. (2010). A proposal of fiscal incentives to accelerate geothermal development in Indonesia. J. Geotherm. Res. Soc., 32, 97-108.

Lawless, J. (2013). Business Models for Successful Geothermal Electricity Development, Director: Ram Power, downloaded on September 2016

Nizhizawa, T. (2016). A renewed Wave of Infrastructure Finance, Public Private Partnership, Lecture and discussion at Master of Planning and Public Policy Program, Faculty of Economic and Business, University of Indonesia, November 2016

Rahardjo, S. (2013). Geothermal in Indonesia (Over Views) Operation Director PT pertamina geothermal energy. Mei 2013.

Vernier, R. \& Jaudin, F. (2013). EGRIF: A Risk Insurance For Geothermal Projects, Geothermal Energy.

Yong, J. (2016). Mechanism of Fiscal and Taxation Policies in the Geothermal Industry in China, EnergiesOpen Access Energy Research, Engineering and Policy. 